\title{
Pengaruh Islamic Branding, Kualitas Produk, dan Lifestyle terhadap Minat Pembelian Produk Skincare pada Generasi Millenial di Kabupaten Kudus
}

\author{
Aryanti Muhtar Kusuma1 ${ }^{1}$, Maulida Ainul Hikmah ${ }^{2}$, Aufarul Marom ${ }^{3}$ \\ Institut Agama Islam Negeri Kudus ${ }^{123}$ \\ aryantimuhtarkusuma@gmail.com ${ }^{1}$, maulidahikmah02@gmail.com² ${ }^{2}$ \\ aufarul505@gmail.com ${ }^{3}$
}

\begin{abstract}
Skincare products become one of beauty products need for increasing beauty and facial health. Needs in fulfiling facial care including economic treatment change on Millenial Generation. Bassed on fenomenon, this research is aimed to know islamic branding, product quality, and lifestyle to interest of skincare product purchase to Millenial Generation in Kudus Regency. Analysing methode use is kuantitatife research with multiple linier regression technique using SPSS'16. Sampling used is non probability sampling and purposive sampling. Research result shows that Islamic branding has signifcant influence to purchase of skincare product, products quality have signifcant influence to purchase of skincare product, and lifestyle has signifcant influence to purchase of skincare products.
\end{abstract}

Keywords: Islamic Branding, Product Quality, Lifestyle, Purchase Interest, Skincare Product, Millenial Generation

\begin{abstract}
Abstrak
Produk skincare menjadi salah satu produk kecantikan yang dibutuhkan untuk penunjang kecantikan serta kesehatan kulit wajah. Kebutuhan dalam pemenuhan perawatan kulit wajah termasuk dalam perubahan pola perilaku ekonomi pada generasi millennial. Berdasarkan fenomena ini penelitian ini bertujuan untuk mengetahui Pengaruh Islamic Branding, Kualitas Produk, dan Lifestyle terhadap Minat Pembelian Produk Skincare pada Generasi Millenial di Kabupaten Kudus. Metode penelitian yang digunakan adalah penelitian kuantitatif dengan teknik regresi linier berganda menggunakan SPSS'16. Pengambilan sampel yang digunakan adalah metode non probability sampling dan purposive sampling. Hasil penelitian menunjukkan bahwa Islamic Branding berpengaruh signifikan terhadap Minat Pembelian Produk Skincare, Kualitas Produk berpengaruh signifikan terhadap Minat Pembelian Produk Skincare dan Lifestyle berpengaruh signifikan terhadap Minat Pembelian Produk Skincare.
\end{abstract}

Kata Kunci: Islamic Branding, Kualitas Produk, Lifestyle, Minat Pembelian, Produk Skincare, Generasi Milenial. 


\section{PENDAHULUAN}

Jenis produk kosmetik skincare menjadi salah satu produk kecantikan yang dibutuhkan untuk penunjang kecantikan serta kesehatan kulit wajah. Kebutuhan dalam pemenuhan perawatan kulit wajah termasuk dalam perubahan pola perilaku ekonomi pada generasi millenial. Generasi millenial atau generasi Y disebut generation me atau echo boomers merupakan kelompok generasi dengan patokan usia mulai awal tahun kelahiran 1980-an hingga tahun 2000-an (Hana, 2019).

Perkembangan era modernisasi menyebabkan adanya perubahan pola perilaku ekonomi pada generasi millenial yang berbeda dengan generasigenerasi sebelumnya. Dilihat dari penggunaan teknologi di media sosial salah satunya digunakan dalam memenuhi kebutuhan perawatan kulit wajah atau skincare. Menurut Female Daily Blog 2018 melalui media sosial sebagai keperluan informasi skincare dapat diketahui dari skincare shelfie maupun berbagai review produk skincare keluaran terbaru.

Munculnya berbagai trend kecantikan mengenai skincare dapat memberikan pengaruh pada seseorang untuk lebih aware mengenai perawatan kulit dengan baik dan benar. Generasi millenial di dunia saat ini memiliki tingkat daya beli kurang lebih 21\% dari 1 triliun dolar, yang memiliki pengaruh besar pada generasi yang lebih tua atau generasi sebelumnya (Wiejayanti, 2018:60). Berdasarkan hal tersebut, perawatan kecantikan kulit wajah atau skincare menjadi salah satu minat daya beli generasi millenial yang menjadi kebutuhan wajib terpenuhi. Kesadaran akan perawatan kecantikan kulit wajah serta peningkatan jumlah pendapatan perkapita yang mencapai Rp 56 juta pertahun, membuat konsumen semakin tertarik untuk melakukan pembelian produk perawatan kulit wajah atau skincare (Laucereno, 2019). Hal-hal tersebut dianggap sebagai faktor yang memberikan peluang bagi industri kecantikan di Indonesia yang terus mengalami pertumbuhan secara signifikan.

Perkembangan pada industri kecantikan di bidang kosmetik tahun 2019 menurut Kementrian Perindustrian terjadi peningkatan 9\% lebih tinggi dibanding pertumbuhan tahun sebelumnya yakni 7,3\% (Ekarina, 2019). Hal tersebut didasarkan pada munculnya berbagai jenis trend kecantikan yang mempengaruhi pola konsumsi oleh generasi millenial dalam memenuhi gaya hidup dan disesuaikan dengan trend mode yang sedang booming. Produsen pada industri kecantikan harus memahami perilaku konsumen yang disesuaikan dengan trend dan permintaan yang diinginkan konsumen. Perbedaan usia maupun perilaku konsumen menjadi faktor yang mempengaruhi minat konsumen untuk membeli produk skincare, utamanya pada konsumen wanita. Hal ini sesuai dengan hasil survei yang menyebutkan bahwa $27 \%$ perempuan Indonesia menginginkan adanya label halal pada suatu produk (Nurfadilah, 2018).

Indonesia merupakan negara dengan mayoritas jumlah penduduk Muslim terbesar di dunia. Dilihat dari adanya jumlah penduduk Muslim di Indonesia yang diprediksi akan meningkat dari tahun 2010 yang berjumlah 
Pengaruh Islamic Branding, Kualitas Produk, dan Lifestyle terhadap Minat Pembelian Produk Skincare pada Generasi Millenial di Kabupaten Kudus

209,12 juta jiwa dari total penduduk 239,89 juta jiwa hingga 263,92 juta jiwa di tahun 2020 (Kusnandar, 2019). Melihat hal tersebut maka, potensi pasar yang besar dapat dimanfaatkan oleh produsen industri kecantikan dengan banyaknya jumlah konsumen Muslim. Trend perawatan kecantikan atau skincare yang sedang berkembang saat ini adalah halal life style, dimana umat Islam dapat merasakan kedamaian ketika mampu mengonsumsi produk halal yang digunakan pada kehidupan sehari-hari (Madevi, 2019:21). Fenomena ini juga terjadi pada generasi millenial yang berada pada salah satu daerah di Indonesia, tepatnya di Kabupaten Kudus dimana sebagian besar penduduk Kudus adalah mayoritas beragama Islam.

Generasi millenial di Kudus dalam memenuhi kebutuhan hidup disesuaikan dengan adanya kehalalan suatu produk, diantaranya pada minat beli produk skincare. Dilihat dari munculnya beragam jenis skincare yang berada di Kudus, baik produk skincare yang diperoleh pada klinik kecantikan dengan bantuan perawat maupun dokter, diantaranya seperti pada Muntira, Larissa, London Beauty Center (LBC), maupun jenis skincare yang diperoleh secara langsung pada pasar swalayan maupun toko online yang dapat digunakan sendiri di rumah.

Munculnya berbagai jenis produk skincare di pasaran yang berada di Kabupaten Kudus menjadikan konsumen lebih berhati-hati ketika tertarik pada produk skincare. Minat pembelian dilakukan dengan adanya pengaruh tertentu dalam diri seseorang maupun pengaruh dari luar sehingga menyebabkan konsumen memiliki keinginan melakukan pembelian produk perawatan kecantikan kulit wajah. Menurut Kotler dan Amstrong yang dikutip dalam jurnal Harahap 2019, menyatakan bahwa kualitas produk adalah kemampuan yang dimiliki suatu produk dalam menjalankan fungsinya baik pada daya tahan yang dimiliki produk, keandalan, ketepatan, kemudahan penggunaan dan perbaikan serta atribut bernilai lain yang dimiliki produk. Generasi millenial di Kudus menjadi selektif sebelum menggunakan produk skincare, dengan melakukan pencarian informasi serta pertimbangan baik dari sosial media maupun pengalaman pemakaian sebagai penilaian kualitas produk sehingga memiliki pengaruh pada minat membeli produk skincare sebagai penunjang penampilan. Generasi millenial saat ini dalam menggunakan produk skincare disesuaikan dengan trend yang berhubungan dengan lifestyle, semakin tinggi level gaya hidup seseorang berpengaruh pada meningkatnya keinginan atau minat seseorang dalam melakukan pembelian. Lifestyle atau gaya hidup generasi millenial saat ini sebagian besar tertarik menggunakan produk skincare sebagai penunjang penampilan, sehingga berpengaruh pada minat untuk membeli produk skincare.

Islamic branding berhubungan dengan munculnya fenomena ragam jenis produk skincare yang akan menjadikan generasi millenial semakin selektif dalam memiliki minat pembelian. Adanya fenomena tersebut dikarenakan banyaknya konsumen Muslim di Kudus dalam penggunaan produk skincare yang mengacu pada merek Islam ataupun identitas yang 
berkaitan pada Islam. Konsumen Muslim yang menggunakan produk skincare sebagai penunjang penampilan dalam menggunakan produk skincare menghubungkan dengan Islamic branding ketika memiliki minat pembelian.

Penelitian tentang kepedulian mahasiswa terhadap kehalalan (Islamic branding) produk kosmetik serta dampaknya terhadap minat beli (Mardalis dan Utami, 2018) menunjukkan bahwa adanya pengaruh yang signifikan pada variabel Islamic branding, kualitas produk dan lifestyle pada minat pembelian produk. Perbedaan pada penelitian yang akan dilakukan yakni pada penelitian sebelumnya hanya meneliti pada minat pembelian produk kosmetik dengan responden mahasiswa kampus tertentu. Sedangkan pada penelitian ini berbeda, dimana penelitian yang dilakukan lebih luas mengenai minat pembelian pada produk skincare dengan populasi responden dari generasi millenial di Kabupaten Kudus.

Namun penelitian terdahulu yang lain menunjukkan bahwa terdapat perbedaan dengan hasil pada penelitian yang menyebutkan bahwa Islamic brand tidak memiliki pengaruh secara signifikan terhadap purchase intention atau minat beli (Nadia, 2014: 130).

Menurut (Shanti dan Hendrawan, 2016) hasil penelitian yang dilakukan menyebutkan bahwa adanya pengaruh positif dari kualitas produk terhadap minat beli. Perbedaan dengan penelitian sebelumnya adalah penelitian hanya meneliti minat pembelian pada kosmetik lipstik wardah, sedangkan dalam penelitian ini akan melakukan penelitian pada minat pembelian produk skincare.

Islamic branding yang berpengaruh pada minat pembelian produk skincare merupakan suatu kebaruan penelitian, diketahui dari penelitian sebelumnya Islamic branding digunakan untuk meneliti minat pembelian hanya pada jenis kosmetik dan sebagian besar meneliti pada minat pembelian selain skincare atau produk lain.

Penelitian yang telah dilakukan sebelumnya dinyatakan adanya hasil yang berbeda dari masing-masing variabel dalam pengaruh Islamic branding, kualitas produk, dan lifestyle terhadap minat pembelian produk. Sehingga dilakukan penelitian lanjutan ini dengan tujuan penelitian perlu dilakukan dalam pengembangan penelitian yang telah dilakukan sebelumnya menggunakan subjek berbeda sehingga dapat mengetahui hasil dari penelitian, dan memberikan pengetahuan, pemahaman serta kemampuan bagi pihak tertentu berdasarkan fenomena yang sedang terjadi pada masyarakat. Penelitian yang akan dilakukan diantaranya memberikan manfaat khususnya bagi para produsen produk kecantikan atau skincare dalam memproduksi produk skincare hingga memasarkan produknya.

Berdasarkan fenomena dan perbedaan hasil dari penelitian sebelumnya dalam latar belakang belakang masalah yang telah diuraikan, maka penulis tertarik untuk membahas masalah penelitian dengan judul "Pengaruh Islamic Branding, Kualitas Produk, dan Lifestyle terhadap Minat Pembelian Produk Skincare pada Generasi Millenial di Kabupaten Kudus)". 
Pengaruh Islamic Branding, Kualitas Produk, dan Lifestyle terhadap Minat Pembelian Produk Skincare pada Generasi Millenial di Kabupaten Kudus

\section{KAJIAN LITERATUR \\ Perilaku Konsumen}

Perilaku konsumen merupakan seluruh aktifitas individu yang secara langsung berkaitan dalam memperoleh dan menggunakan barang maupun jasa termasuk didalamnya proses pengambilan keputusan dalam persiapan maupun penentuan dalam tindakan. Adapun proses terbentuknya perilaku konsumen terdapat beberapa tahapan, yaitu perolehan atau acquisition, mencari atau searching, membeli atau purchasing, konsumsi atau consumption, menggunakan atau using, mengevaluasi atau evaluating, dan tindakan pasca beli atau dispositi (Annisa dan Suyanto, 2019: 343). Perilaku konsumen terfokus pada proses tindakan yang dilakukan individu sampai terdapat keputusan untuk menggunakan sumber daya yang tersedia dalam melakukan konsumsi.

\section{Minat Pembelian}

Minat beli merupakan bagian dari komponen perilaku konsumen dalam mengkonsumsi maupun kecenderungan konsumen untuk bertindak sebelum melakukan keputusan untuk membeli (Mega dan Teguh, 2012:151). Peningkatan minat beli konsumen dapat dilihat dari beberapa faktor, yakni faktor sosial dan faktor psikis. Faktor sosial yang mempengaruhi minat beli konsumen dipengaruhi oleh keluarga, kelompok, dan status sosial yang kemudian dipengaruhi adanya pemberdayaan bauran pemasaran yang terdiri dari produk, harga, promosi, dan distribusi. Faktor psikis dalam mempengaruhi minat beli merupakan faktor pendorong yang berasal dari dalam diri konsumen yaitu sikap, persepsi, motivasi, dan pengetahuan (Annisa dan Suyanto, 2019: 343). Minat membeli merupakan suatu tindakan yang berasal dari keinginan pribadi dengan tendensi yang relatif terhadap merek (Arifin dan Fachrodji 2015:131). Berdasarkan pengertian tersebut dapat disimpulkan bahwa minat pembelian merupakan sikap kecenderungan dalam perilaku konsumen untuk membeli suatu produk, dimana dalam proses pembelian berasal dari beberapa pertimbangan maupun pencarian informasi produk hingga tindakan yang berhubungan dengan pembelian produk atau merek

\section{Islamic Branding}

Islamic branding merupakan penggunaan identitas yang melekat pada suatu produk dengan menunjukkan nama, simbol maupun karakteristik lainnya yang membedakan dengan produk lain dengan menggunakan unsur Islam baik dalam nama, komposisi, maupun proses pembuatan yang disesuaikan dengan ketentutan syariat Islam. Menurut Swimberghe et al. menyatakan bahwa kepercayaan agama yang tertanam dalam diri seseorang atau konsumen sesuai dengan keputusan dalam pemiilihan konsumsi. Berdasarkan hal tersebut, dapat dikatakan bahwa jika jumlah konsumen Muslim yang memiliki ketaatan terhadap agama terus mengalamipeningkatan, maka akan mempengaruhi peningkatan pada pilihan konsumsi yang didasarkan padaIslamic brand (Fitriya, 2017: 33-34). 


\section{Kualitas Produk}

Menurut Kotler dan Amstrong dalam Harahap dan Hidayat 2019, menyatakan bahwa kualitas produk adalah kemampuan yang dimiliki suatu produk dalam menjalankan fungsinya baik pada daya tahan yang dimiliki produk, keandalan, ketepatan, kemudahan penggunaan dan perbaikan serta atribut bernilai lain yang dimiliki produk. Kualitas produk meliputi karakteristik dari produk yang bergantung pada kemampuan suatu produk dalam memberikankepuasan untuk memenuhi kebutuhan konsumen yang dapat di implikasikan. Hubungan pemasar dengan kualitas produk atau product quality dimana kualitas produk menjadi salah satu positioning utama yang dibutuhkan dalam menarik konsumen. Kualitas secara umum menunjukkan kemampuan yang dimiliki produk secara langsung, sehingga berhubungan erat dengan penilaian yang dimiliki produk serta berdampak pada kepuasaan pelanggan (Rachma, 2018:4). Berdasarkan penjelasan tersebut, dapat disimpulkan kualitas produk merupakan suatu kemampuan yang dimiliki produk dan ditunjukkan untuk mempengaruhi keinginan konsumen dalam membeli produk yang disesuaikan dengan keinginan individu dalam memenuhi kebutuhan sehingga memberikan kepuasan menggunakan suatu produk dan meningkatkan serta mempertahankan konsistensi produk dihadapan konsumen.

\section{Lifestyle}

Lifesyle adalah suatu pola hidup seseorang yang ditunjukkan dalam kehidupannya dengan diwujudkan pada kegiatan yang dilakukan, keinginan atau minat yang dimiliki, dan adanya pendapat atau opini terhadap sesuatu hal yang terjadi (Kamaludin dan Muhajirin, 2018:115). Teori gaya hidup atau lifestyle menyebutkan bahwa setiap orang akan memiliki gaya hidup yang berbeda, sesuai dengan faktor yang mempengaruhinya seperti adanya perbedaan umur, jenis kelamin, pendidikan, status perkawinan, pendapatan keluarga, dan ras yang berkaitan dengan rutinitas kehidupan sehari-hari (Vina, 2015:27).

Dengan adanya gaya hidup menurut menjadikan peluang yang besar bagi pemasar dalam menciptakan suatu produk baru dalam memenuhi kebutuhan yang disesuaikan dengan gaya hidup konsumen (Hanif dan Masreviastuti, 2018:326). Menurut (Prasetijo dan John, 2005: 56-57) Lifestyle dalam diri seseorang dapat berubah diantaranya dipengaruhi adanya lingkungan maupun kebutuhan hidup, konsumen akan mengevaluasi dengan alternatif yang ada dengan atribut produk yang menjajikan dalam pemenuhan kebutuhan gaya hidup yang dianutnya. Maka berdasarkan penjelasan tersebut, lifestyle atau gaya hidup dapat disimpulkan sebagai pola atau model hidup yang melekat pada diri seseorang yang ditunjukkan berdasarkan aktifitas yang dilakukan, pendapat yang dimiliki mengenai suatu hal, dan keinginan atau minat yang dimiliki seseorang dalam melakukan sesuatu. 
Pengaruh Islamic Branding, Kualitas Produk, dan Lifestyle terhadap Minat Pembelian Produk Skincare pada Generasi Millenial di Kabupaten Kudus

\section{Kerangka Berfikir}

Penelitian ini akan membahas mengenai pengaruh Islamic branding, kualitas produk, dan lifestyle terhadap minat pembelian produk skincare pada generasi millenial di Kabupaten Kudus dengan kerangka berfikir pada gambar sebagai berikut:

\section{Gambar 1}

\section{Kerangka Berfikir}

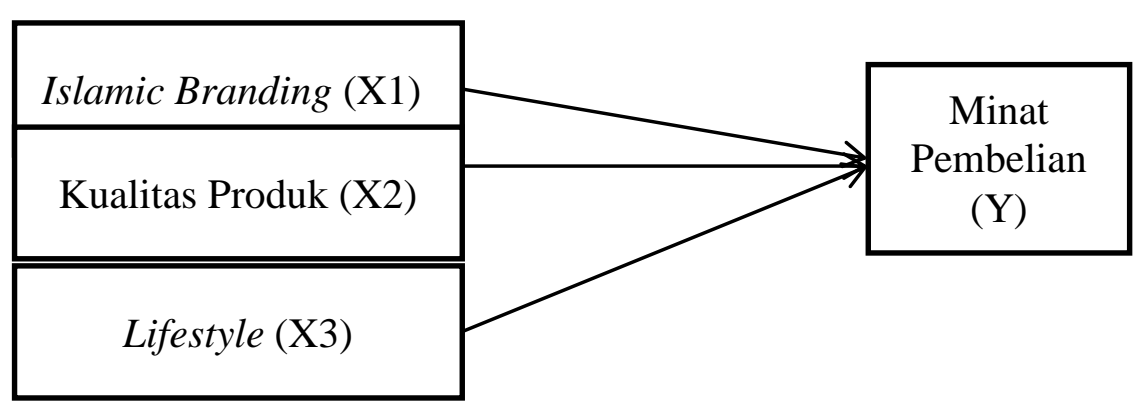

\section{METODE PENELITIAN}

Jenis penelitian yang digunakan dalam penelitian ini adalah penelitian kuantitatif. Adapun populasi pada penelitian ini adalah generasi masyarakat millenial di Kabupaten Kudus yang memiliki minat pembelian produk skincare. Metode pengambilan sampel yang digunakan dalam penelitian ini merupakan metode non probability sampling dan purposive sampling. Maka jumlah sampel yang digunakan dalam penelitian ini sebesar 150 responden dengan kriterianya adalah masyarakat dengan jenis kelamin wanita di Kabupaten Kudus, dengan batas usia 18-45 tahun dengan penggolongan usia ( $<25$ tahun, 25-29 tahun, dan $>29$ tahun) yang memiliki minat beli produk skincare baik produk skincare local yang tedapat pada toko-toko kosmetik maupun berasal dari situs toko online, serta skincare klinik kecantikan. Alat analisis untuk mengetahui pengaruh Islamic Branding, Kualitas Produk dan Lifestyle terhadap Minat Pembelian Produk Skincare pada Generasi Millenial di Kabupaten Kudus adalah dengan Regresi Linier Berganda dengan menggunan SPSS'16.

\section{PEMBAHASAN \\ Uji Instrumen}

Dalam penelitian ini berdasarkan pengujian validitas dari seluruh indikator pertanyaan dinyatakan valid dengan Corrected Item-Total Correlation $\mathrm{r}$ hitung $>\mathrm{r}$ tabel (Sugiyono, 2017) dengan nilai 0,361. Berdasarkan uji Reliabilitas dari semua indikator pertanyaan dalam penelitian ini dinyatakan realible bahwa nilai Cronbach's Alpha $>0,60$ sehingga bisa dikatakan hasil pengukuran tetap konsisten dan dapat digunakan untuk mengolah data selanjutnya. 
Uji Statistik

Pada penelitian ini dilakukan uji statistik yaitu Uji $F$ dan $R$ Koefisien Determinasi $\left(\mathrm{R}^{2}\right)$ dengan hasil sebagai berikut:

Tabel Hasil Uji F

ANOVA $^{\mathrm{b}}$

\begin{tabular}{|c|c|c|c|c|c|c|}
\hline \multicolumn{2}{|c|}{ Model } & $\begin{array}{l}\text { Sum of } \\
\text { Squares }\end{array}$ & Df & Mean Square & $\mathrm{F}$ & Sig. \\
\hline \multirow[t]{3}{*}{1} & Regression & 1282.543 & 3 & 427.514 & 35.700 & $.000^{\mathrm{a}}$ \\
\hline & Residual & 1748.397 & 146 & 11.975 & & \\
\hline & Total & 3030.940 & 149 & & & \\
\hline
\end{tabular}

a. Predictors: (Constant), Lifestyle, Islamic Branding, Kualitas

Produk

b. Dependent Variable: Minat Pembelian

Sumber: Data Primer yang Diolah SPSS'16, 2020

Berdasarkan hasil analisis uji F pada variabel bebas (Islamic branding, kualitas produk, dan lifestyle) menunjukkan nilai $F_{\text {hitung }} 35,700$ dengan nilai $F_{\text {tabel }} 2,67$ ini berarti $F_{\text {hitung }}$ lebih besar dari $F_{\text {tabel }}(35,700>2,67)$ dengan nilai probabilitas 0,001 yang lebih kecil dari tingkat siginfikansi 0,05. Dengan demikian variabel bebas (Islamic branding, kualitas produk, dan lifestyle) secara simultan berpengaruh signifikan terhadap minat pembelian

Tabel Hasil Uji Koefisien Determinasi $\left(\mathbf{R}^{2}\right)$

Model Summary

\begin{tabular}{l|r|r|r|r}
\hline Model & R & R Square & Adjusted R Square & \multicolumn{2}{|c}{$\begin{array}{c}\text { Std. Error of the } \\
\text { Estimate }\end{array}$} \\
\hline 1 & $.650^{\mathrm{a}}$ & .423 & .411 & 3.461 \\
\hline
\end{tabular}

a. Predictors: (Constant), Lifestyle, Islamic Branding, Kualitas Produk

Sumber: Data Primer yang Diolah SPSS'16, 2020

Berdasarkan tabel diketahui bahwa koefisien determinasi besarnya 0,411 . Hal tersebut berarti minat pembelian dapat dijelaskan oleh variabel Islamic branding, kualitas produk, dan lifestyle yang diturunkan dalam model sebesar $41,1 \%$, atau dengan kata lain sumbangan efektif (kontribusi) variabel independen terhadap variasi (perubahan) minat pembelian sebesar 41,1\%. Variasi minat pembelian bisa dijelaskan oleh variasi dari ketiga variabel independen yaitu Islamic branding, kualitas produk, dan lifestyle, jadi sisanya sebesar $(100 \%-41,1 \%=58,9 \%)$ minat pembelian dijelaskan oleh variabeivariabel lain yang tidak dimasukkan dalam penelitian ini.

\section{Analisis Regresi Linier}

Model analisis regresi linear berganda digunakan untuk mengetahui persamaan regresi pengaruh Islamic branding, kualitas produk, dan lifestyle 
Pengaruh Islamic Branding, Kualitas Produk, dan Lifestyle terhadap Minat Pembelian Produk Skincare pada Generasi Millenial di Kabupaten Kudus

terhadap minat pembelian pada produk skincare. Berdasarkan data estimasi diperoleh data sebagai berikut:

Coefficients $^{\mathrm{a}}$

\begin{tabular}{|c|c|c|c|c|c|c|}
\hline \multirow{2}{*}{\multicolumn{2}{|c|}{ Model }} & \multicolumn{2}{|c|}{$\begin{array}{l}\text { Unstandardized } \\
\text { Coefficients }\end{array}$} & \multirow{2}{*}{\begin{tabular}{|c} 
Standardized \\
Coefficients
\end{tabular}} & \multirow[b]{2}{*}{$\mathrm{T}$} & \multirow[b]{2}{*}{ Sig. } \\
\hline & & B & Std. Error & & & \\
\hline \multirow[t]{4}{*}{1} & (Constant) & 7.149 & 2.177 & & 3.284 & .001 \\
\hline & $\begin{array}{l}\text { Islamic } \\
\text { Branding }\end{array}$ & .295 & .090 & .241 & 3.274 & .001 \\
\hline & $\begin{array}{l}\text { Kualitas } \\
\text { Produk }\end{array}$ & .297 & .105 & .240 & 2.842 & .005 \\
\hline & Lifestyle & .377 & .088 & .327 & 4.290 & .000 \\
\hline
\end{tabular}

a. Dependent Variable: Minat Pembelian

Sumber: Data Primer yang Diolah SPSS'16, 2020

Berdasarkan tabel tersebut diperoleh persamaan regresi pengaruh Islamic branding, kualitas produk, lifestyle terhadap minat pembelian produk skincare sebagai berikut:

$$
\begin{aligned}
& Y=a+b_{1} X_{1}+b_{2} X_{2}+b_{3} X_{3}+e \\
& Y=7,149+0,295 X_{1}+0,297 X_{2}+0,377 X_{3}+0,05
\end{aligned}
$$

Berdasarkan nilai koefisien regresi dari variabel-variabel yang mempengaruhi minat pembelian dengan menggunakan taraf signifikansi $\alpha=$ 0,05 dapat diinterpretasikan sebagai berikut:

a. Konstanta sebesar 7,149 menyatakan jika Islamic branding ( $\left.\mathrm{X}_{1}\right)$, kualitas produk $\left(\mathrm{X}_{2}\right)$, lifestyle $\left(\mathrm{X}_{3}\right)$ nilainya nol, maka minat pembelian (Y) akan mengalami peningkatan sebesar nilainya 7,149 atau $71,49 \%$.

b. Koefisien regresi variabel Islamic branding $\left(\mathrm{X}_{1}\right)$ sebesar 0,295 artinya jika variabel independen lain nilainya tetap dan Islamic branding mengalami kenaikan $1 \%$, maka minat pembelian (Y) akan mengalami peningkatan sebesar 0,295.

c. Koefisien regresi variabel kualitas produk(X2) sebesar 0,297 artinya jika variabel independen lain nilainya tetap dan kualitas produk mengalami kenaikan 1\%, maka minat pembelian (Y) akan mengalami peningkatan sebesar 0,29.

d. Koefisien regresi variabel lifestyle (X3) sebesar 0,377 artinya jika variabel independen lain nilainya tetap dan lifestyle mengalami kenaikan 1\%, maka minat pembelian (Y) akan mengalami peningkatan sebesar 0,377. 
Uji t

Berdasarkan hasil analisis uji $\mathrm{t}$ untuk variabel bebas (Islamic branding) menunjukkan nilai thitung 3,274 dengan nilai tabel 1,976 ini berarti thitung lebih besar dari tabel $(3,274>1,976)$ dengan nilai probabilitas 0,001 yang lebih kecil dari tingkat signifikansi 0,05. Dengan demikian variabel bebas (Islamic branding) berpengaruh sangat signifikan terhadap minat pembelian. Berdasarkan hasil analisis uji t untuk variabel bebas (kualitas produk) menunjukkan nilai thitung 2,842 dengan nilai tabel 1,976 ini berarti thitung lebih besar dari tabel $(2,842>1,976)$ dengan nilai probabilitas 0,005 yang lebih kecil dari tingkat signifikansi 0,05. Dengan demikian variabel bebas (kualitas produk) berpengaruh sangat signifikan terhadap minat pembelian. Berdasarkan hasil analisis uji t untuk variabel bebas (lifestyle) menunjukkan nilai thitung 4,290 dengan nilai tabel 1,976 ini berarti thitung lebih besar dari tabel $(4,290>1,976)$ dengan nilai probabilitas 0,000 yang lebih kecil dari tingkat signifikansi 0,05. Dengan demikian variabel bebas (lifestyle) berpengaruh sangat signifikan terhadap minat pembelian

\section{Pengaruh Islamic Branding terhadap Minat Pembelian}

Variabel Islamic branding memiliki pengaruh terhadap minat pembelian produk skincare pada generasi millenial di Kabupaten Kudus, hal ini dibuktikan dari hasil pengolahan data dengan menggunakan SPSS versi 16 dapat diketahui bahwa nilai thitung 3,274 dengan nilai tabel 1,976 ini berarti thitung lebih besar dari tabel $(3,274>1,976)$ dengan nilai probabilitas 0,001 yang lebih kecil dari tingkat signifikansi 0,05. Berdasarkan hasil olah data tersebut, secara parsial Islamic branding merupakan variabel bebas yang berpengaruh signifikan terhadap minat pembelian produk skincare pada generasi millenial di Kabupaten Kudus, dan thitung positif artinya Islamic branding berpengaruh positif terhadap minat pembelian.

Islamic branding merupakan penggunaan nama atau merek berupa simbol sebagai karakteristik pada produk serta proses pembuatan maupun komposisi bahan yang seluruhnya berkaitan dengan ketentuan syariat Islam atau identitas kehalalan suatu produk (Nasrullah, 2018:82). Pemilihan pembelian produk yang mengacu pada Islamic brand memberikan kepercayaan pada konsumen bahwa produk yang digunakan halal sesuai dengan syariat agama. Hal tersebut sesuai dengan teori menurut Swimberghe et al. yang menyatakan bahwa kepercayaan agama yang tertanam dalam diri seseorang atau konsumen sesuai dengan keputusan dalam pemilihan konsumsi. Islamic branding yang terdapat dalam produk mempengaruhisegmentasi pasar yang dituju pada konsumen Muslim. Dilihat dari jumlah masyarakat mayoritas Muslim maka hal tersebut menjadikan produsen memiliki sasaran produk, dengan memperoleh identitas produk yang berkaitan dengan Islam, sehingga dapat mempengaruhi konsumen utamanya Muslim memiliki keyakinan serta minat untuk melakukan pembelian terhadap suatu produk, yakni skincare. 
Pengaruh Islamic Branding, Kualitas Produk, dan Lifestyle terhadap Minat Pembelian Produk Skincare pada Generasi Millenial di Kabupaten Kudus

Berdasarkan hasil penelitian menunjukkan bahwa Islamic branding berpengaruh sangat signifikan terhadap minat pembelian produk skincare pada generasi millenial di Kabupaten Kudus. Hal tersebut sesuai dengan hasil penelitian terdahulu yang dilakukan oleh Mardalis dan Utami 2015 dengan judul "Kepedulian Mahasiswa Terhadap Kehalalan (Islamic Branding) Produk Kosmetik Serta Dampaknya Terhadap Minat Beli” yang menyatakan bahwa Islamic branding berpengaruh signifikan terhadap minat beli.

\section{Pengaruh Kualitas Produkterhadap Minat Pembelian}

Variabel kualitas produk memiliki pengaruh terhadap minat pembelian produk skincare pada generasi millenial di Kabupaten Kudus, hal ini dibuktikan dari hasil pengolahan data dengan menggunakan SPSS versi 16 dapat diketahui bahwa nilai thitung 2,842 dengan nilai tabel 1,976 ini berarti thitung lebih besar dari tabel $(2,842>1,976)$ dengan nilai probabilitas 0,005 yang lebih kecil dari tingkat signifikansi 0,05. Berdasarkan hasil olah data tersebut, secara parsial kualitas produkmerupakan variabel bebas yang berpengaruh signifikan terhadap minat pembelian produk skincare pada generasi millenial di Kabupaten Kudus, dan thitung positif artinya kualitas produkberpengaruh positif terhadap minat pembelian.

Kualitas suatu produk diketahui konsumen berdasarkan persepsi dari penilaian suatu produk yang berasal dari pemenuhan kebutuhan yang disesuaikan dengan keinginan. Menurut Kotler dan Amstrong dalam jurnal Rachma 2018, menyatakan bahwa kualitas produk adalah kemampuan yang dimiliki suatu produk dalam menjalankan fungsinya baik pada daya tahan yang dimiliki produk, keandalan, ketepatan, kemudahan penggunaan dan perbaikan serta atribut bernilai lain yang dimiliki produk (Harahap dan Hidayat, 2019:3). Kualitas yang dimiliki suatu produk akan ditunjukkan secara langsung pada kinerja suatu produk, diantaranya produk skincare. Sehingga penilaian yang menimbulkan persepsi baik buruk terhadap produk yang akan digunakan akan mempengaruhi konsumen dalam memiliki minat untuk membeli produk skincare yangdapat menjadi penunjang penampilan seseorang.

Berdasarkan hasil penelitian menunjukkan bahwa kualitas produkberpengaruh sangat signifikan terhadap minat pembelian produk skincare pada generasi millenial di Kabupaten Kudus. Hal tersebut sesuai dengan hasil penelitian yang dilakukan oleh Shanti dan Hendrawan 2016 dengan judul "Pengaruh Brand Image, Kualitas Produk, dan Reference Group Terhadap Minat Beli Produk Kosmetik Lipstik Wardah di Kota Malang" dengan kesimpulan bahwa kualitas produkberpengaruh signifikan terhadap minat beli.

\section{Pengaruh Lifestyle terhadap Minat Pembelian}

Variabel lifestyle memiliki pengaruh terhadap minat pembelian produk skincare pada generasi millenial di Kabupaten Kudus, hal ini dibuktikan dari hasil pengolahan data dengan menggunakan SPSS versi 16 
dapat diketahui bahwa nilai thitung 4,290 dengan nilai ttabel 1,976 ini berarti thitung lebih besar dari ttabel $(4,290>1,976)$ dengan nilai probabilitas 0,000 yang lebih kecil dari tingkat signifikansi 0,05. Berdasarkan hasil olah data tersebut, secara parsial lifestyle merupakan variabel bebas yang berpengaruh signifikan terhadap minat pembelian produk skincare pada generasi millenial di Kabupaten Kudus, dan thitung positif artinya lifestyle berpengaruh positif terhadap minat pembelian.

Hal tersebut sesuai yang dikemukakan oleh Faizah 2018 menyatakan bahwa gaya hidup termasuk dalam perilaku konsumen memiliki pengaruh pada tindakan yang dilakukan konsumen untuk melakukan pembelian suatu produk. Lifestyle sebagai pola hidup yang dimiliki seseorang yang dapat ditunjukkan melalui beberapa hal diantaranya aktifitas yang dilakukan seseorang, minat, maupun pendapat seseorang terhadap suatu hal (Kholifah dan Rulyanto, 2015). Gaya hidup yang dimiliki seseorang berkaitan dengan perkembangan zaman serta kemajuan teknologi yang berdampak pada semakin berkembang luas penerapan gaya hidup seseorang dalam kehidupan sehari-hari. Gaya hidup mencerminkan keseluruhan pribadi yang telah tertanam dalam dirinya dan berdampak pada tindakan konsumsi sehingga gaya hidup mempengaruhi seseorang dalam memiliki minat pembelian, diantaranya pada produk skincare.

Berdasarkan hasil penelitian menunjukkan bahwa Islamic branding berpengaruh sangat signifikan terhadap minat pembelian produk skincare pada generasi millenial di Kabupaten Kudus. Penelitian tersebut sejalan dengan hasil penelitian yang dilakukan oleh Kamaluddin dan Muhajirin dengan judul penelitian "Pengaruh Gaya Hidup Terhadap Minat Beli Konsumen Dalam Berbelanja Online (Studi Kasus Pada Mahasiswa STIE BIMA) dengan hasil bahwa lifestyle berpengaruh signifikan terhadap minat beli.

\section{SIMPULAN}

Berdasarkan hasil analisis dan pembahasan pada penelitian ini dapat disimpulkan bahwa variabel islamic branding memiliki pengaruh signifikan terhadap minat pembelian produk skincare pada Generasi Millenial di Kabupaten Kudus . Variabel kualitas produk memiliki pengaruh signifikan terhadap minat pembelian produk skincare pada Generasi Millenial di Kabupaten Kudus. Begitupun dengan variabel lifestyle memiliki pengaruh signifikan terhadap minat pembelian produk skincare pada Generasi Millenial di Kabupaten Kudus. Hal ini mengisyaratkan bahwa Generasi Milenial di Kabupaten Kudus melakukan pembelian produk skincare dengan mengutamakan atau memperhatikan islamic branding, kualitas produk dan lifestyle. 
Pengaruh Islamic Branding, Kualitas Produk, dan Lifestyle terhadap Minat Pembelian Produk Skincare pada Generasi Millenial di Kabupaten Kudus

\section{DAFTAR PUSTAKA}

Annisa, Dinda dan Ama Suyanto. (2019): Pengaruh Gaya Hidup Terhadap Minat Beli Pada Konsumen Dan Followers Tuskbag Official,"eProceedings of Management 6 (1). 343.

Arifin, Endro dan Achmad Fachrodji,. (2005). Pengaruh Persepsi Kualitas Produk, Citra Merek, Dan Promosi Terhadap Minat Beli Konsumen Ban Achilles Di Jakarta Selatan.131.

Ekarina, .Tren Perawatan Kecantikan Naik, Industri Kosmetik Dipatok Tumbuh 9\%," 10 April, 2019, https://katadata.co.id/berita/2019/04/10/tren-perawatankecantikan-naik-industri-kosmetik-dipatok-tumbuh-9.

Elok Fitriya. (2017). Analisis Pengaruh Islamic Branding Terhadap Keputusan Konsumen Untuk Membeli Produk," Jurnal Ilmiah Akuntansi Indonesia 2 (1).33.

Faizah, Hanif dan Masreviastuti. (2018).Pengaruh Gaya Hidup dan Islamic Branding TerhadapKeputusan Pembelian Produk Wardah. 326.

Female Daily, diakses pada 24 Januari, 2020, https://editorial.femaleday.com/blog/2018/09/13/efek-sampingbanyaknya-informasi-tentang-skincare/.

Hana, Kharis Fadlullah. (2019). Minat Beli Online Generasi Milenial: Pengaruh Kepercayaan dan Kualitas Layanan. Jurnal Bisnis dan Manajemen Islam 7, (2). 206.

Harahap, Ipa Audina Br. dan Wahyu Hidayat. 2019. Pengaruh Kualitas Produk dan Harga Terhadap Keputusan Pembelian Masker Wajah Mustika Ratu (Studi Kasus pada Konsumen Kec. Tembalang Kota Semarang),": 3

Kamaluddin dan Muhajirin. (2018). Pengaruh Gaya Hidup Terhadap Minat Beli Konsumen Dalam Berbelanja Online (Studi Kasus Pada Mahasiswa STIE BIMA).Jurnal Akrab Juara Vol 3 (2).

Kholifah, Fitria Nur dan Rulirianto. 2015. Pengaruh Gaya Hidup dan Kelompok Referensi Terhadap Keputusan Pembelian Lipstik MerkWardah (Studi Pada Mahasiswi Program Studi D-IV Manajemen Pemasaran Jurusan Administrasi Niaga Politeknik Negeri Malang). Jurnal Aplikasi Bisnis

Kotler, P dan G. Amstrong. 2008. Manajemen Pemasaran. Edisi ketiga belas. Jilid dua. Jakarta: Erlangga.

Kusnandar Viva Budi.Jumlah Penduduk Indonesia Menurut Agama (20102050), 24 September, 2019, https://databoks.katadata.co.id/datapublish/2019/09/24/berapajumlah-penduduk-Muslim-indonesia.

Madevi, Fadhila dkk. (2019). Pengaruh Persepsi Label Halal Terhadap Citra Merek dan Minat Beli. Jurnal Administrasi Bisnis 77, no.(1). 21. 
Mardalis, Ahmad dan Sari Utami,. (2018). Kepedulian Mahasiswa Terhadap Kehalalan (Islamic Branding) Produk Kosmetik Serta Dampaknya Terhadap Minat Beli. University Research Colloquium (Urecol).

Mega, Petra Surya W. dan Christina Teguh,. (2012). Faktor-Faktor Yang Mempengaruhi Minat Beli Di Online Shop Specialis Guess," JRMB 7 (2). 151.

Nadia, Nor Sara M. Y. et al. (2014). Muslim's Purchase Intention towards NonMuslim's Halal Packaged Food Manufacturer. ScienceDirect , Procedia - Social and Behavioral Sciences. 130.

Nasrullah, Muhammad. (2015). Islamic Branding, Religiusitas Dan Keputusan Konsumen Terhadap Produk. Jurnal Hukum Islam (JHI), Volume 13 (2)

Nurfadilah,Putri Syifa. Industri Kecantikan di Indonesia Tumbuh Pesat Hingga 16 Persen," Kompas, 20 Agustus, 2018, https://amp.kompas.com/ekonomi/read/2018/08/20/14085332 6/industri-kecantikan-di-indonesia-tumbuh-pesat-hingga-16persen.

Prasetijo, Ristiayanti dan John J.O.I Ihalauw. 2005. Perilaku Konsumen . Yogyakarta. 56-57.

Siti Rachma. (2018). Pengaruh Harga Dan Kualitas Produk Terhadap Keputusan Pembelian Kosmetik Sariayu Martha Tilaar Di Konter Martha Tilaar Pasar Swalayan Ada Semarang. Jurnal Ilmu Administrasi Bisnis 7(4).

Shanti, Mardhatilah dan Dimas Hendrawan, (2016). Pengaruh Brand Image, Kualitas Produk, dan Reference Group Terhadap Minat Beli Produk Kosmetik Lipstik Wardah di Kota Malang," Jurnal Ilmiah Mahasiswa $3,(2)$.

Sugiyono. (2017). Metode Penelitian Kuantitatif, Kualitatif dan R\&D. Bandung: Alfabeta

Swimberghe, Kris R, dkk. (2017). Actual and Ideal- Self Congruence and dual brand passion. Journal of Consumer Marketing.

Sylke Febrina Laucereno. Pendapatan Perkapita RI Naik Jadi Rp 56 Juta Pertahun," 06 Februari, 2019, https://m.detik.com/finance/beritaekonomi-bisnis/d-4415935/pendapatan-per-kapita-ri-naik-jadirp-56-juta-per-tahun.

Vina, Sri Yuniarti. 2015. Perilaku Konsumen. Bandung: Pustaka Setia.

Wiejayanti, Syelvi dkk. (2018). Pengaruh Penerimaan Pasar Dan Strategi Bauran Pemasaran Terhadap Minat Beli Produk Makeup Anak Pada Millenial Mom (Penelitian di Wilayah DKI Jakarta). Jurnal Ilmiah Kedokteran 5 (3):60 